\title{
Pleckstrin Homology-Like Domain Family B Member 3
}

National Cancer Institute

\section{Source}

National Cancer Institute. Pleckstrin Homology-Like Domain Family B Member 3. NCI

Thesaurus. Code C132185.

Pleckstrin homology-like domain family B member 3 ( $640 \mathrm{aa}, \sim 72 \mathrm{kDa}$ ) is encoded by the human PHLDB3 gene. This protein may be involved in interacting with enzymes. 